\title{
A SECOND HOST SPECIES OF THE INQUILINE ANT LEPTOTHORAX WILSONI
}

\author{
By J. Heinze, B. Trunzer, K. Lechner, And D. Ortius \\ Theodor-Boveri-Institut (Biozentrum der Universität) \\ LS Verhaltensphysiologie und Soziobiologie \\ Am Hubland, D-97074 Würzburg, FRG
}

\begin{abstract}
The workerless parasitic ant, Leptothorax wilsoni, as yet known only from colonies of Leptothorax cf. canadensis, was found in five colonies of a second host species, Leptothorax sp. A (sensu Heinze and Buschinger, 1989) near Escoumins, Québec. This is the first finding of an inquiline with more than one host species in the ant tribe Formicoxenini. In contrast to a previous statement, the palp formula of $L$. wilsoni is 4,3 .
\end{abstract}

\section{INTRODUCTION}

The ant Leptothorax wilsoni was described from New England, Québec, and New Brunswick (Heinze, 1989). Since then it has repeatedly been collected at the type locality, Mt. Monadnock in southern New Hampshire (Heinze unpubl.), and recently it was found also in Alberta and Montana (Buschinger and Schumann, 1994). L. wilsoni is an inquiline ant, i.e., a workerless social parasite, living in colonies of a large black Leptothorax (s.str.), which has been referred to as Leptothorax sp. B or, more recently, Leptothorax cf. canadensis (Heinze, 1994). Here we report on the occurrence of $L$. wilsoni in colonies of a second host species, Leptothorax sp. A, an as yet undescribed but well characterized taxon (e.g., Heinze and Buschinger, 1989; Heinze, 1991).

\section{METHODS}

In September 1994 and May 1995, we collected four colonies of L. wilsoni in a pine-aspen-birch forest between Bergeronnes and

Manuscript received 13 March 1995. 


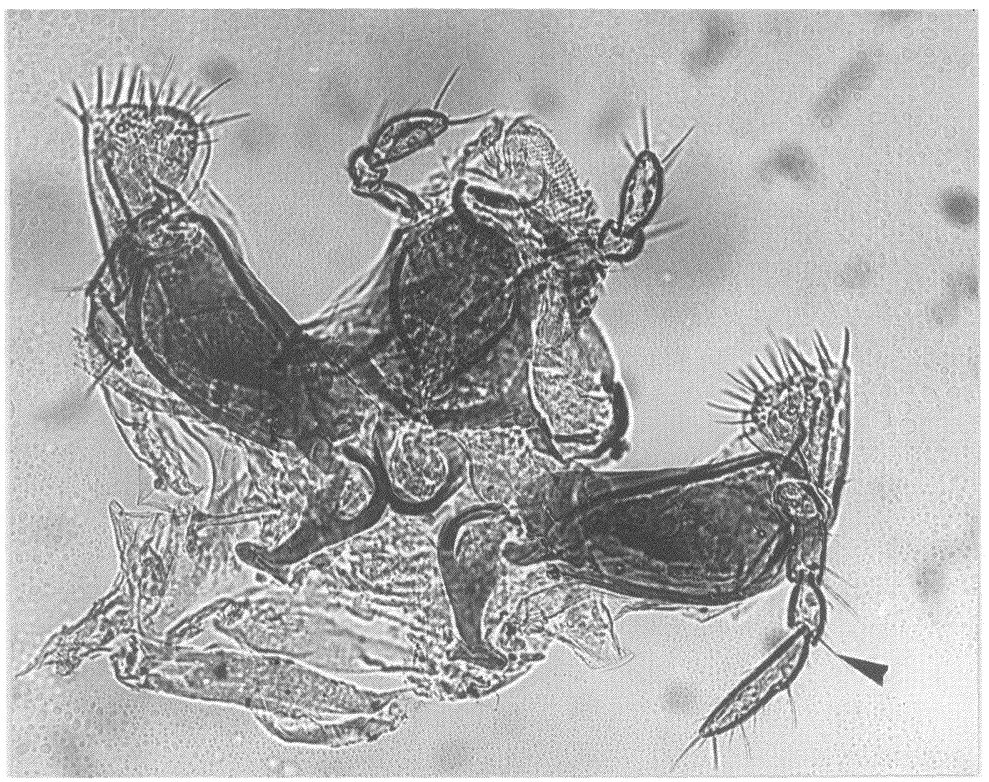

Fig. 1: Labium and maxillae of a Leptothorax wilsoni queen from Escoumins, Québec. The arrow points to the 4-segmented maxillary palp.

Escoumins (Co. de Saguenay, Québec), $4 \mathrm{~km}$ east of Cap Bon Désir, on a road branching off route 138 to the north and leading to a garbage dump ("Depotoir"). A fifth colony was found approximately $0.5 \mathrm{~km}$ north of the first site on rocky outcrops with scattered spruces and pines. Colonies nested in rotting sticks in partly shaded areas directly along the road, on a forest path, and on the edge of a rocky patch.

\section{RESULTS AND DisCUSSION}

Of a total of 65 Leptothorax colonies collected in these two sites, 14 were $L$. cf. canadensis and 36 were $L$. sp. A, as determined by the trapezoidal shape of their postpetiole in dorsal view, the length of the epinotal spines, and the electrophoretic migration velocity of several enzyme markers (e.g., Heinze, 1991). Three $L$. sp. A colonies contained each a gynomorphic, i.e., an originally normal, alate queen of $L$. wilsoni, 5,10 , and more than 50 host 
workers, respectively, and brood. In both of the two remaining colonies, an "intermorphic," i.e., originally brachypterous $L$. wilsoni queen with 50 to 60 host workers and brood was found. $L$. wilsoni from the Escoumins sites did not differ conspicuously in morphology from specimens from Mt. Monadnock and Jasper National Park, though they were somewhat lighter in coloration. Specimens from Escoumins, Jasper, and Mt. Monadnock also share a very slowly migrating variant of the enzyme malate dehydrogenase (MDH) not known from other Leptothorax (Heinze, 1991). Queen polymorphism in L. wilsoni was assumed on the basis of several short-winged "intermorphs" from Mt. Monadnock and one gynomorphic queen from Mt. du Lac des Cygnes in Québec (Heinze, 1989). The co-occurrence of both queen morphs within a single population (and even within the same host colony) was only recently confirmed for a population in Alberta (Buschinger and Schumann, 1994). Our finding shows that both queen morphs cooccur also in Québec.

Host queens have not been found in L. wilsoni colonies from other populations (Heinze, 1989 and unpublished; Buschinger and Schumann, 1994); however, in one colony from Escoumins, an intermorphic $L$. wilsoni queen and a gynomorphic $L$. sp. A queen occurred together. Dissection of the $L$. sp. A queen revealed the presence of sperm in the spermatheca and elongated ovaries, but neither developing eggs nor corpora lutea were found. The whitish coloration of the fat body and the ovarian development suggest that the $L$. sp. A queen was a young queen which had returned into the parasitized nest after mating without becoming fertile.

In July 1988, at the Mt. Monadnock site a solitary queen of $L$. wilsoni was collected near a nest of Leptothorax sp. A. This finding was initially interpreted as an accidental mixing of a solitary $L$. wilsoni queen, searching for a $L$. cf. canadensis host colony after mating, and an unparasitized $L$. sp. A colony (Heinze, 1989). Our recent observations raise the possibility that on Mt. Monadnock $L$. wilsoni parasitizes both $L$. cf. canadensis and $L$. sp. A. However, all five fertile $L$. wilsoni queens known from Mt. Monadnock were found with $L$. cf. canadensis, though more than 70 colonies of $L$. sp. A and 100 colonies of $L$. cf. canadensis were checked.

The occurrence of $L$. wilsoni in colonies of a second host species, $L$. sp. A, is especially surprising as workerless parasites 
typically live with only a single host species. In the tribe Formicoxenini (formerly Leptothoracini, Bolton, 1994), which is especially rich in parasites, no other case of an inquiline parasitizing two host species is known, and most inquilines found with more than one host species in other ant tribes are poorly studied (e.g., Tetramorium microgyna; for a complete list see Hölldobler and Wilson, 1990). According to Emery's rule (Emery, 1909; Buschinger, 1990; Bourke and Franks, 1991), inquiline ants originate from the same ancestor as their host species. The restriction of inquilines to single host species has been thought to reflect this close phylogenetic relationship. Based on biochemical data, a close relationship between $L$. wilsoni and its host species is unlikely; it appears that $L$. wilsoni diverged from these and other species early in the evolution of Leptothorax (s.str.) (Heinze, 1991). This is reflected also by the expression of various morphological characters. L. wilsoni apparently differs from all Leptothorax (s.str.) in the number of maxillary palps, which is five in Leptothorax but four in L. wilsoni from Jasper National Park and Escoumins (Fig. 1). The original description (Heinze, 1989), according to which $L$. wilsoni from Mt. Monadnock has five-segmented maxillary palps, might be erroneous in this respect and the palp formula needs to be rechecked in specimens from the type locality. Within the Formicoxenini, some Formicoxenus also have a palp formula of 4, 3 (Bolton, 1982; Francoeur, Loiselle, and Buschinger, 1985). Furthermore, in contrast to other Leptothorax (s.str.), L. wilsoni has some scattered erect hairs on the compound eyes, a character which it shares again with Formicoxenus (Francoeur, Loiselle, and Buschinger, 1985). In other characters that distinguish between Formicoxenus and Leptothorax, such as the relation between width and length of thorax and head, respectively, or scape length in the male, L. wilsoni is closer to Leptothorax (Heinze, 1989 and unpub1.). The morphological peculiarities of $L$. wilsoni, which apparently are not special adaptations to its parasitic life, suggest that a more detailed assessment of its placement within the Formicoxenini would prove rewarding.

\section{ACKNOWLEDGEMENTS}

Field work in Canada was supported by the Deutsche Forschungsgemeinschaft (He 1623/2-2). 


\section{Literature Cited}

Bolton, B. 1982. Afrotropical species of the myrmicine ant genera Cardiocondyla, Leptothorax, Melissotarsus, Messor and Cataulacus (Formicidae). Bull. Brit. Mus. Nat. Hist. 45:307-370.

Bolton, B. 1994. Identification guide to the ant genera of the world. Harvard Univ. Press, Cambridge, Mass.

Bourke, A.F.G., and Franks, N.R. 1991. Alternative adaptations, sympatric speciation and the evolution of parasitic, inquiline ants. Biol. J. Linn. Soc. 43:157-178.

Buschinger, A. 1990. Sympatric speciation and radiative evolution of socially parasitic ants - heretic hypotheses and their factual background. Z. Zool. Syst. Evol.Forschung. 28:241-260.

Buschinger, A., and Schumann, R. 1994. Records of Leptothorax wilsoni Heinze 1989, from western North America. Psyche 101:13-18.

Emery, C. 1909. Über den Ursprung der dulotischen, parasitischen und myrmekophilen Ameisen. Biol. Zentralbl. 29:352-362.

Francoeur, A., Loiselle, R., and Buschinger, A. 1985. Biosystématique de la tribu Leptothoracini (Formicidae, Hymenoptera). 1. Le genre Formicoxenus dans la région holarctique. Naturaliste can. (Rev. Écol. Syst.) 112:343-403.

Heinze, J. 1989. Leptothorax wilsoni n. sp., a new parasitic ant from eastern North America (Hymenoptera: Formicidae). Psyche 96:49-61.

Heinze, J. 1991. Biochemical studies on the relationship between socially parasitic ants and their hosts. Biochem. Syst. Ecol. 19:195-206.

Heinze, J. 1994. Genetic colony and population structure of the ant Leptothorax cf. canadensis. Can. J. Zool. 72:1477-1480.

Heinze, J., and Buschinger, A. 1989. Queen polymorphism in Leptothorax spec. A: its genetic and ecological background (Hymenoptera: Formicidae). Insectes Soc. 36:139-155.

Hölldobler, B., and Wilson, E.O. 1990. The Ants. Belknap Press of Harvard University Press, Cambridge, Mass. 

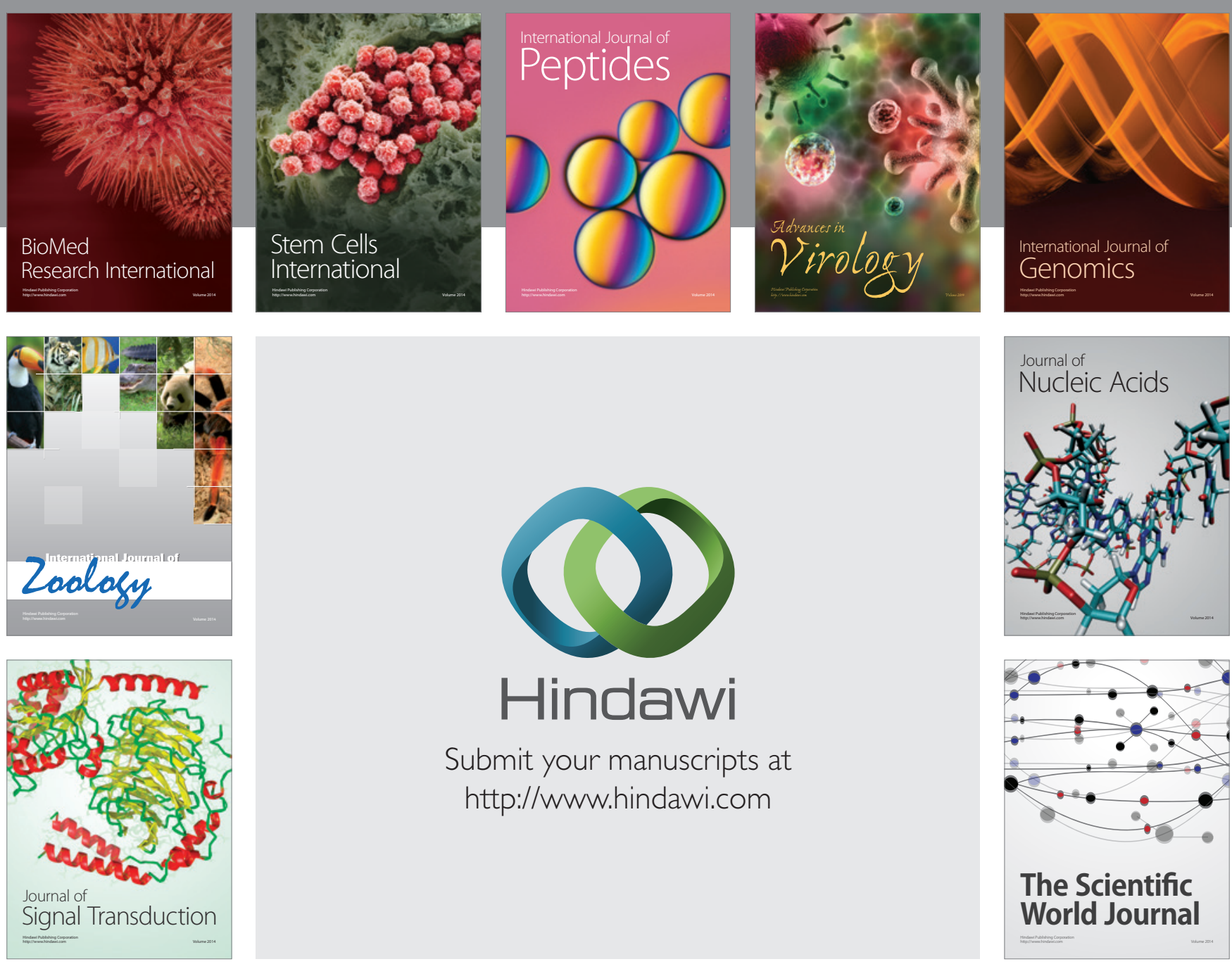

Submit your manuscripts at

http://www.hindawi.com
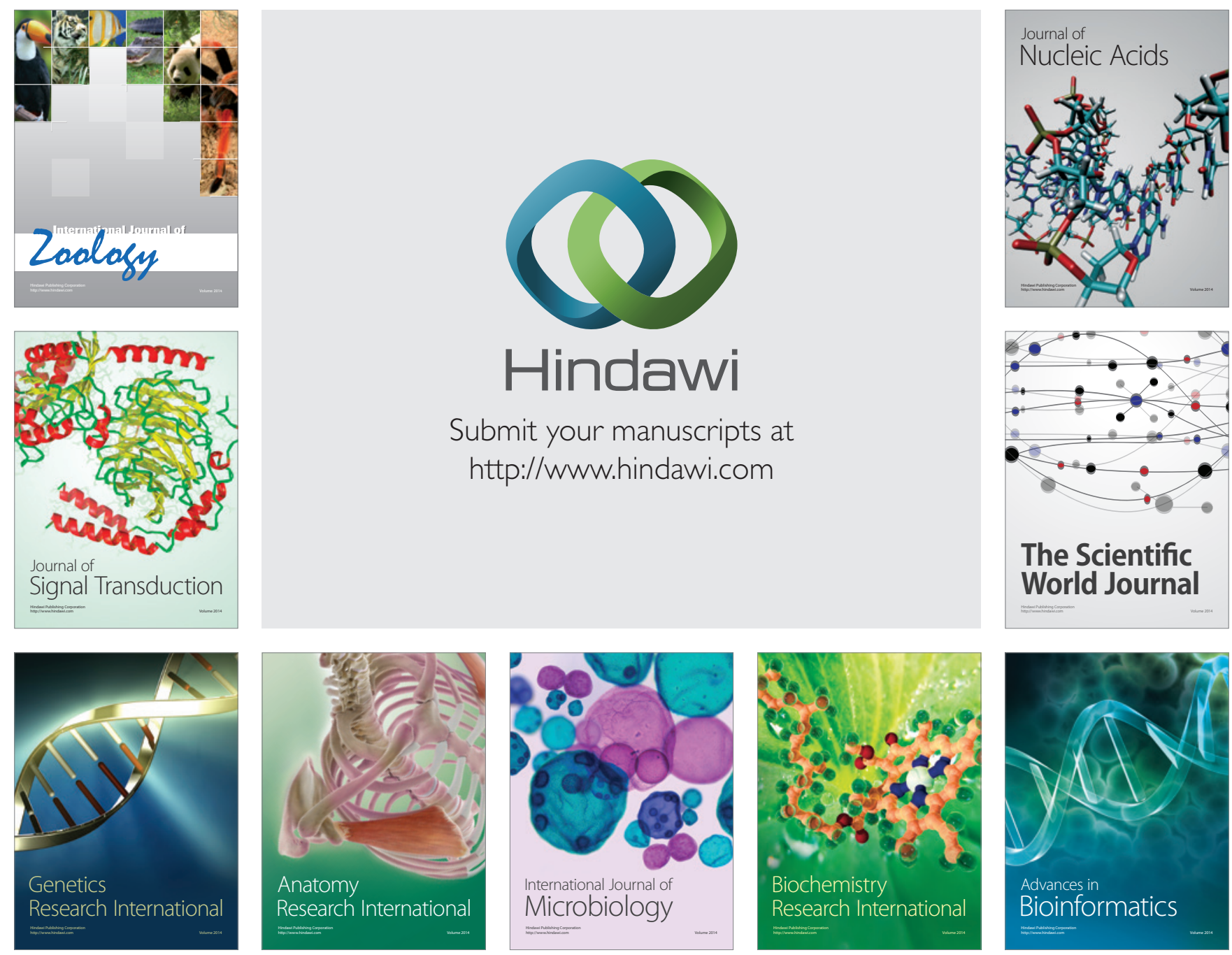

The Scientific World Journal
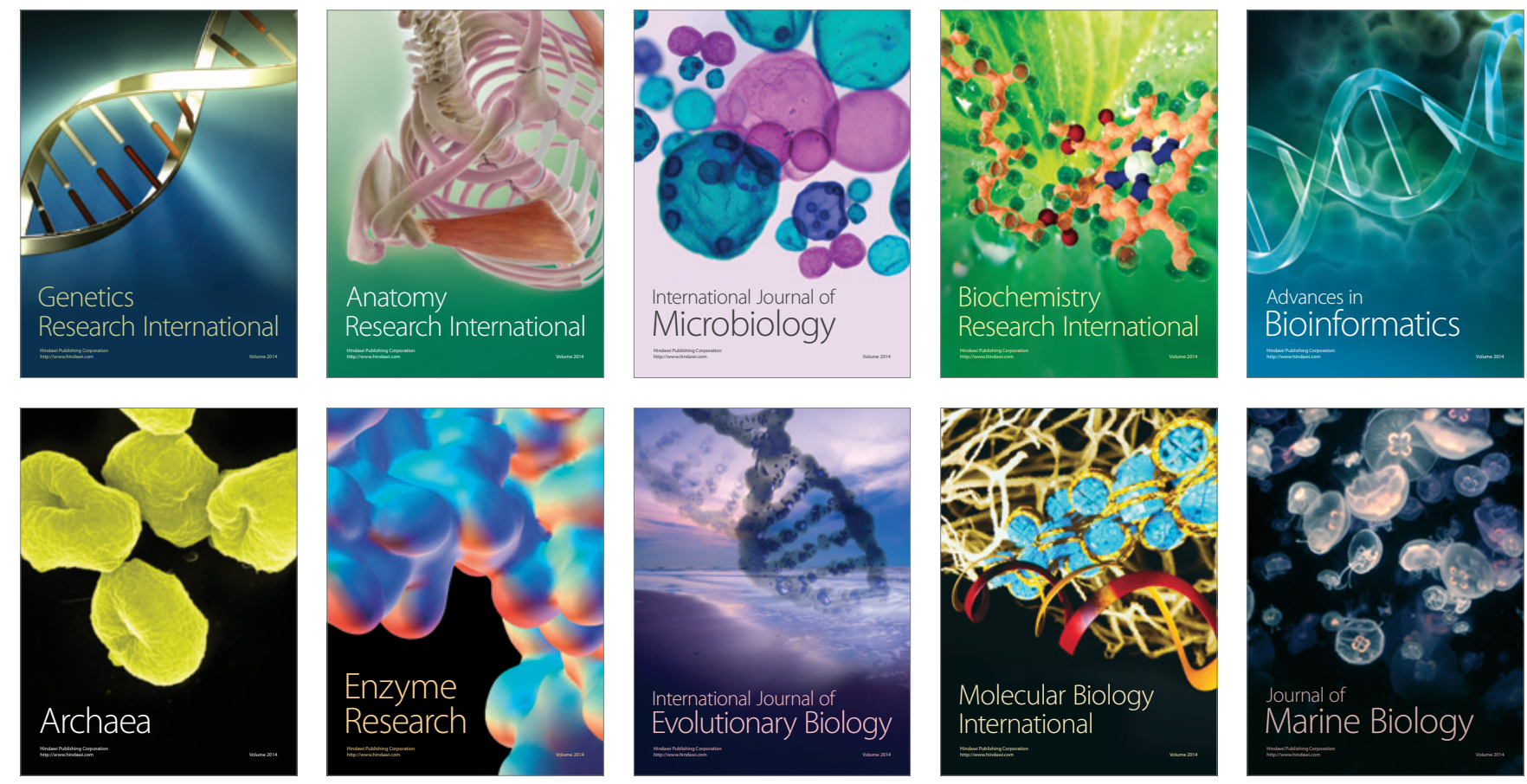